\title{
5. International Law on Arctic Fisheries
}

Erik J. Molenaar

\subsection{Introduction}

Due to climate change in particular, the international law on Arctic fisheries is attracting ever more attention. Climate change may give rise to new fishing opportunities in the Arctic due to receding sea-ice and poleward shifts of fish stocks as well as expected species invasions (Christiansen et al. 2014; Jones and Cheung 2014). But receding sea-ice could also have negative impacts on some Arctic fish stocks, and increased fresh-water inflow and pollution - particularly from Russian rivers - as well as the possibility of oceanacidification, could act as a counterbalance to these new fishing opportunities leading potentially to an actual decrease. Notwithstanding this however, sea-ice regression in the Arctic means that the North Pacific and North Atlantic Oceans will become increasingly connected.

This chapter will focus on marine capture fisheries in the Arctic, without devoting attention to freshwater fisheries, aquaculture, and marine mammals as target species. A number of (potentially) significant commercial fish stocks currently occur in the marine Arctic. The ranges of distribution of some of these are confined to the North Pacific or the North Atlantic, while others have a circumpolar distribution. Important North Pacific fish stocks include Alaska pollock (Theragra chalcogramma), Pacific cod (Gadus macrocephalus), snow crab (Chionoecetes opilio) and various Pacific salmon species (Oncorhynchus spp.). As regards the North Atlantic, important fish stocks include North-East Arctic cod (Gadus morhua), haddock (Melanogrammus aeglefinus), Norwegian spring-spawning (Atlantoscandian) herring (Clupea harengus), Atlantic salmon (Salmo salar) and 
red king crab (Paralithodes camtschaticus). Significant circumpolar fish stocks include capelin (Mallotus villosus), Greenland halibut (Reinhardtius hippoglossoides) and northern shrimp (Pandalus borealis). Polar cod and Arctic char (Salvelinus alpinus) also have circumpolar distribution, but the former is only marginally targeted by commercial fisheries and the latter is predominantly fished for subsistence purposes.

There are no generally accepted geographical definitions for the terms "Arctic", "marine Arctic" and "Arctic Ocean". For the purpose of this chapter, the term "marine Arctic" corresponds to the marine waters included within the boundary agreed by the Arctic Council's Conservation of Arctic Flora and Fauna (CAFF) working group (see Figure 1 below). The "Arctic Ocean" is defined in this chapter as the marine waters north of the Bering Strait, Greenland, Svalbard, and Franz Josef Land, excluding the Barents Sea. There are four high seas pockets in the marine Arctic, namely the socalled "Banana Hole" in the Norwegian Sea, the so-called "Loophole" in the Barents Sea, the so-called "Donut Hole" in the central Bering Sea, and the so-called "Central Arctic Ocean". 
Figure 1: The Arctic Region: General Overview

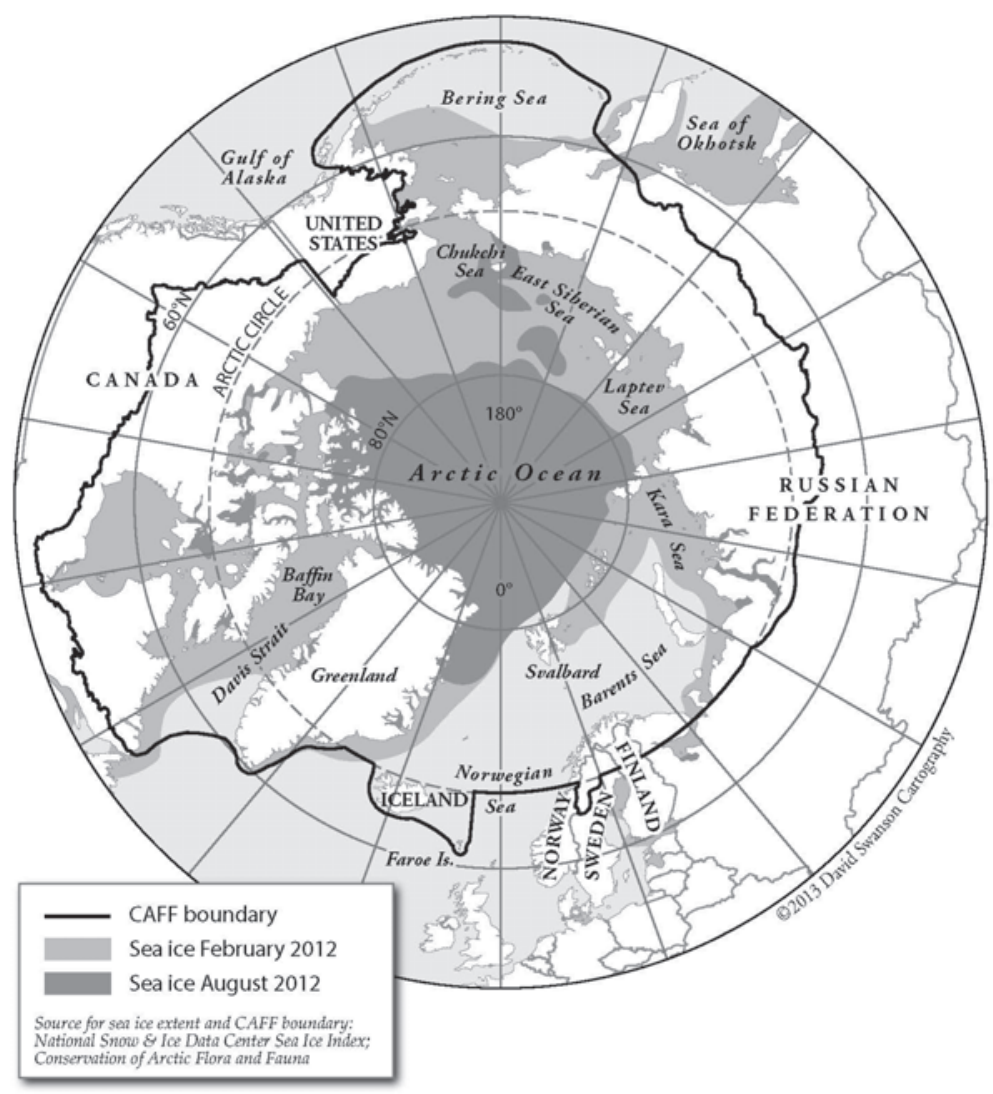

Canada, Denmark/Greenland, Norway, the Russian Federation, and the United States are "Arctic Ocean coastal states". These five plus Finland, Iceland, and Sweden are "Arctic states" on account of their membership of the Arctic Council.

At the time of writing, large-scale commercial fisheries were taking place in the Barents and Bering Seas. The fisheries that occurred in the Arctic Ocean were essentially limited to small-scale subsistence fisheries in coastal state maritime zones. No fisheries occurred at all in the Central Arctic Ocean. 


\subsection{The Global Component of International Fisheries Law}

International fisheries law is the body of international law that relates specifically to the conservation, management and/or development of capture fisheries. It consists of substantive norms (e.g., rights and obligations), substantive fisheries standards (e.g., catch restrictions) as well as institutional rules and arrangements (e.g., mandates and decision-making procedures of international bodies). International fisheries law is part of general international law and can also be seen as a branch or part of the international law of the sea.

The global component of international fisheries law applies to the marine Arctic and the (Central) Arctic Ocean, however defined. Its jurisdictional framework is provided first of all by the 1982 United Nations Convention on the Law of the Sea (UNCLOS). The UNCLOS contains, among other things, rules on the geographical extent of maritime zones and the basic rights and obligations of states therein.

Three categories of maritime zones can be distinguished as follows, first, coastal state maritime zones that belong to a coastal state's territory and are thereby subject to its sovereignty, namely, internal waters, archipelagic waters and a territorial sea with a maximum width of 12 nautical miles (nm). Within these zones, a coastal state has exclusive access and unlimited jurisdiction over marine living resources. The UNCLOS does not apply its key obligations on conservation and management of marine living resources (see below) to these maritime zones. Second, coastal state maritime zones that are not part of a coastal state's territory but in which the coastal state has functional jurisdiction relating to fisheries; these are the $200 \mathrm{~nm}$ Exclusive Economic Zone (EEZ) or Exclusive Fishery Zone (EFZ) and the continental shelf, which can extend beyond $200 \mathrm{~nm}$. Within its EEZ or EFZ, a coastal state has sovereign rights over all marine living resources and thereby exclusive access and jurisdiction, but subject to the aforementioned key obligations of the UNCLOS. With respect to its continental shelf, a coastal state has sovereign rights over so-called "sedentary species" and thereby exclusive access and jurisdiction. The aforementioned key obligations of the UNCLOS do not apply. And third, maritime

zones beyond coastal state jurisdiction, namely, the high seas and the 
deep sea-bed (the Area). The UNCLOS confirms the right for all states - in their capacity as flag states - to fish on the high seas. This right also applies to the Area.

Apart from archipelagic waters, all these maritime zones also occur in the Arctic. The division of the marine Arctic into maritime zones is therefore essentially the same as in other seas and Oceans, except for the Southern Ocean, due to the dispute on sovereignty over Antarctic territory. A maritime zone that is unique to the marine Arctic is the Fisheries Protection Zone (FPZ) established by Norway seaward of the territorial sea around Svalbard. Norway's choice for an FPZ instead of an EEZ or EFZ was motivated by the diverging views among states on the spatial scope of the 1920 Spitsbergen Treaty (Molenaar 2012).

The UNCLOS restricts the entitlements to fisheries that states have in their capacities as coastal or flag states, through various key obligations. Due to the adoption of other global fisheries instruments, in particular the 1995 Fish Stocks Agreement (1) - an implementation agreement of the UNCLOS - several legally binding and non-legally binding instruments adopted by the United Nations Food and Agriculture Organization (FAO) as well as certain (parts of) United Nations General Assembly (UNGA) Resolutions (Molenaar 2013a), these key obligations have gradually developed into the following:

1. To avoid over-exploitation of target species by means of setting a science-based total allowable catch (TAC), which strives for maximum sustainable yield (MSY) as qualified by the precautionary approach.

2. To strive for the optimum utilisation of target species within the EEZ or EFZ by providing other states with access to the surplus of the TAC.

3. To pursue an ecosystem approach to fisheries (EAF), which often focuses in particular on (a) predator-prey relationships; (b) impacts of fisheries on non-target species and the ecosystem as a whole; and (c) impacts of oceanographic or climate processes, or pollution, on fish stocks.

4. To cooperate in relation to transboundary fish stocks and fish stocks that occur exclusively on the high seas.

5. To exercise effective jurisdiction and control over a state's own vessels. 
The UNCLOS, the Fish Stocks Agreement and the FAO's fisheries instruments are primarily concerned with establishing the jurisdictional framework. They do not contain substantive fisheries standards such as catch restrictions through TACs, allocations of fishing opportunities through national quotas, gear restrictions or temporal/seasonal or spatial measures (e.g., closed areas). Actual fisheries regulation is carried out by states individually or collectively. The primary means for collective regulation is through regional fisheries management organisations (RFMOs), which have the mandate to impose legally binding fisheries conservation and management measures on their members. The Fish Stocks Agreement designates RFMOs as the preferred vehicle for the conservation and management of straddling fish stocks (i.e., stocks occurring within the maritime zones of one or more coastal states and on the high seas) and highly migratory fish stocks (e.g., tuna).

\subsection{Arctic Fisheries Instruments and Bodies}

A considerable number of regional, sub-regional and bilateral fisheries fora and instruments apply to parts of the marine Arctic. A distinction can however be made here between fisheries fora and instruments that apply only to specific more southerly waters of the marine Arctic and those that also apply explicitly to the Arctic Ocean. This distinction is, among other things, relevant for the discussion in section 5.4 "Towards a Regional Instrument on Central Arctic Ocean Fisheries".

The main regional, sub-regional and bilateral fisheries fora and instruments that apply to certain more southerly waters of the marine Arctic but not explicitly to the Arctic Ocean are:

1. The bilateral (Canada and the United States) International Pacific Halibut Commission (IPHC).

2. The bilateral (Canada and the United States) Yukon River Panel of the bilateral Pacific Salmon Commission (PSC).

3. The North Pacific Anadromous Fish Commission (NPAFC).

4. The Western and Central Pacific Fisheries Commission (WCPFC). 
5. The Conference of Parties (COP) to the Convention on the Conservation and Management of Pollock Resources in the Central Bering Sea.

6. The North Atlantic Salmon Conservation Organization (NASCO).

7. The International Commission for the Conservation of Atlantic Tunas (ICCAT).

8. The Northwest Atlantic Fisheries Organization (NAFO).

9. The numerous multilateral and bilateral agreements and arrangements between coastal states and entities (i.e., the European Union (EU)) in the North-East Atlantic, establishing TACs, allocations of fishing opportunities and mutual access to maritime zones (Churchill 2001; Molenaar 2012).

While the fora and instruments under Nos. 1-5 apply to certain more southerly waters of the marine Arctic in the Pacific, Nos. 6-9 apply to certain more southerly waters of the marine Arctic in the Atlantic.

Two fora have competence over (part of) the Arctic Ocean, namely the North-East Atlantic Fisheries Commission (NEAFC) and the Joint Norwegian-Russian Fisheries Commission (Joint Commission). The spatial competence of NEAFC extends to the geographic North Pole and thus comprises a segment of the Arctic Ocean. While the NEAFC Convention Area includes both coastal state maritime zones and the high seas, NEAFC Recommendations mainly apply to the high seas. The spatial competence of the Joint Commission is not defined in its constitutive instrument. The regulatory practice of the Joint Commission nevertheless indicates that its spatial competence comprises both coastal state maritime zones and the high seas in not only the Barents Sea, but also the Norwegian Sea and the Arctic Ocean. The competence-overlap between NEAFC and the Joint Commission does not only exist geographically, but also in species. However, currently there seems to be no - or hardly any - actual conflict between the two bodies' management and conservation measures. Their current relationship can therefore be regarded as complementary. Interestingly, at the time of writing neither fora seemed to be specifically regulating the fisheries for northern shrimp and snow crab in the Loophole. 
While fisheries regulation in the FPZ off Svalbard is in a formal sense undertaken unilaterally by Norway, it is shaped to a quite considerable extent by the provisions on equal access and non-discrimination laid down in the Spitsbergen Treaty. Accordingly, Norway has granted certain allocations of fishing opportunities to a limited number of parties to the Treaty, largely based on historic track records (Molenaar 2012).

Finally, reference should be made to the frequently occurring failure of the North-East Atlantic coastal states and entities - i.e., Denmark (in respect of the Faroe Islands and Greenland), the EU, Iceland, Norway and the Russian Federation - to agree on allocations of fishing opportunities for shared and straddling fish stocks. In recent years, such failures related among other things to Atlanto-Scandian herring and North-East Atlantic mackerel and in 2013 even led Denmark (in respect of the Faroe Islands) to institute dispute settlement proceedings on Atlanto-Scandian herring against the EU in the framework of the UNCLOS as well as the World Trade Organization (WTO). By mid-2014, however, the Faroe Islands and the EU had come to an agreement on the allocation of Atlanto-Scandian herring and both procedures were subsequently terminated.

\subsection{Towards a Regional Instrument on Central Arctic Ocean Fisheries}

The alarming pace of sea-ice regression in the Arctic Ocean and the poleward shift of fish stocks have culminated in various calls for the regulation of Arctic Ocean fisheries. Within the United States, this led to Senate joint (SJ) resolution No. 17 of 2007 directing the United States "to initiate international discussions and take necessary steps with other Nations to negotiate an agreement for managing migratory and transboundary fish stocks in the Arctic Ocean." Subsequently, in 2009 the United States prohibited an expansion of commercial fishing in the EEZ off Alaska in the Arctic Ocean until sufficient information would be available to ensure that fisheries would be conducted in accordance with the EAF and in recognition of the interests of local residents and communities. The Pew Charita-

ble Trusts' Arctic Ocean campaign has lobbied for a similar regime for the Central Arctic Ocean since 2010 (Wegge 2015). 
Intergovernmental interaction on Arctic Ocean fisheries began as early as 2007, with a failed attempt by the United States to initiate the international discussions called for in SJ Resolution No. 17 in the Arctic Council. Following a likewise failed 2009 EU proposal for the UNGA to call for the regulation of Arctic Ocean fisheries, the Arctic Ocean coastal states commenced a process on the regulation of Arctic Ocean fisheries in 2010. This process has so far led to various policy/governance meetings (June 2010, Oslo; April-May 2013, Washington D.C.; and February 2014, Nuuk) as well as science meetings (June 2011, Anchorage; and October 2013, Tromsø). Another science meeting was scheduled to take place sometime in 2015.

The Chairman's Statement of the Nuuk meeting in February 2014 (2) records the Arctic Ocean coastal states' agreement on the desirability of interim measures by which they would commit themselves, among other things, to "authorise their vessels to conduct commercial fishing" in the Central Arctic Ocean "only pursuant to one or more regional or subregional fisheries management organisations or arrangements that are or may be established to manage such fishing in accordance with modern international standards." Once the envisaged interim measure would be adopted, therefore, it would not amount to a ban or moratorium on fishing as such, but only on unregulated fishing. A fishery regulated by NEAFC and possibly even the Joint Commission - but certainly a future regional fisheries instrument or RFMO - would still be possible. Another important aspect of the envisaged interim measures is that they would apply exclusively to the Central Arctic Ocean, and not to coastal state maritime zones.

The Chairman's Statement on the Nuuk meeting also noted that the Arctic Ocean coastal states had agreed to work towards the adoption or signature of a Ministerial Declaration modelled on the draft interim measures agreed in Nuuk as well as the commencement of a broader process involving additional states that would adopt interim measures compatible with the Ministerial Declaration. The outcome of this broader process could be a legally binding regional fisheries instrument. Due to subsequent geopolitical developments in the Crimea and Eastern Ukraine later in 2014, however, neither had yet been realised by the time of writing. 


\subsection{Conclusions and Looking Ahead}

The Chairman's Statement on the Nuuk meeting emphasises that "commercial fishing" in the Central Arctic Ocean "is unlikely to occur in the near future." What was probably meant is that large-scale (nonsubsistence) fishing in the Central Arctic Ocean is unlikely to be commercially viable in the near future. This seems a plausible prediction, and indicates that the envisaged regional instrument on Central Arctic Ocean fisheries will be largely based on the precautionary approach. The efforts of the Arctic Ocean coastal states are therefore highly commendable. Nonsubsistence fishing activities could nevertheless potentially also commence without being commercially viable, for instance by a vessel flying the flag of a state that is not bound by the envisaged regional instrument on Central Arctic Ocean fisheries.

A prediction that is not merely plausible but extremely likely to prove correct is that large-scale fisheries will become commercially viable within coastal state maritime zones of the Arctic Ocean sooner than in the high seas. The more immediate challenge is thus for Arctic Ocean coastal states to ensure that new and exploratory fisheries within their maritime zones are regulated in accordance with the EAF and to take due account of the needs, interests and rights of Arctic Indigenous peoples. The stringency level of such regulation should be similar to that of the envisaged regional instrument on Central Arctic Ocean fisheries. This will be crucial in securing support for the envisaged regional instrument among non-Arctic states and entities, who may even insist on having this reflected in the regional instrument through the inclusion of the notion of compatibility.

Another major future challenge for Arctic fisheries concerns arrangements on the allocation of fishing opportunities. These arrangements must be adjusted to the implications of climate change, which may potentially lead to more frequent, less predictable and larger changes in the abundance and distribution of fish stocks. As noted at the end of section 5.3, several disputes on the allocation of North-East Atlantic fish stocks have arisen in recent years and many more could arise in the future. 


\subsection{Notes}

1. Agreement for the Implementation of the Provisions of the United Nations Convention on the Law of the Sea of 10th December 1982 relating to the Conservation and Management of Straddling Fish Stocks and Highly Migratory Fish Stocks.

2. "Meeting on Arctic Fisheries. Nuuk, Greenland, 24-26th February 2014, Chairman's Statement," http://naalakkersuisut.gl/en/Naalakkersuisut/ News/2014/02/Arktisk-hoejsoefiskeri

\subsection{References}

Christiansen, Jørgen S., Mecklenburg, Catherine W. \& Karamushko, Oleg V. (2014). Arctic Marine Fishes and their Fisheries in Light of Global Change. 20 Global Change Biology 352-359. http://dx.doi.org/10.1111/gcb.12395

Churchill, Robin R. (2001). Managing Straddling Fish Stocks in the North-East Atlantic: A Multiplicity of Instruments and Regime Linkages - but How Effective a Management? In O.S. Stokke (ed.) Governing High Seas Fisheries: The Interplay of Global and Regional Regimes. Oxford: Oxford University Press: 235-272. http://dx.doi.org/10.1093/acprof:oso/9780198299493.003.0009

Jones, Miranda C. \& Cheung, William W.L. (2014). Multi-model Ensemble Projections of Climate Change Effects on Global Marine Biodiversity. ICES Journal of Marine Science, 10th October.

Molenaar, Erik J. (2012). Fisheries Regulation in the Maritime Zones of Svalbard. 27 International Journal of Marine and Coastal Law 3-58. http://dx.doi.org/ $10.1163 / 157180812 X 610541$

Molenaar, Erik J. (2013a). Status and Reform of International Arctic Fisheries Law. In E. Tedsen, S. Cavalieri and R.A. Kraemer (eds.), Arctic Marine Governance: Opportunities for Transatlantic Cooperation (Springer):103-125.

Molenaar, Erik J. (2013b). Arctic Fisheries Management. In E.J. Molenaar, A.G. Oude Elferink and D.R. Rothwell (eds.), The Law of the Sea and the Polar Regions: Interactions between Global and Regional Regimes. Leiden-Boston: Martinus Nijhoff Publishers:243-266. http://dx.doi.org/10.1163/9789004255210_012

Wegge, Njord (2015). The Emerging Politics of the Arctic Ocean. Future Management of the Living Marine Resources. 51 Marine Policy 331-338. http://dx.doi.org/10.1016/j.marpol.2014.09.015 


\subsection{Questions}

- In your view, which future challenges relating to Arctic fisheries regulation are of most concern?

- The geographical scope of the regional instrument currently envisaged by the Arctic Ocean coastal states is limited to the high seas (Central Arctic Ocean). Discuss the consistency of this limitation with international law.

- The Arctic Ocean coastal states eventually intend to commence a broader process involving non-Arctic states. Which states or entities should in your view be involved and based on what rationale? 